\title{
Improving the Quality of Camel Milk Soft Cheese Using Milky Component (BMR) and Sweet Potato Powder
}

\author{
Amal Megahed Elnemr ${ }^{*}$, Mohamed Ali Ahmed ${ }^{1}$, Hatem Helmy Omar Arafat ${ }^{1}$, Sherif Osman ${ }^{1}$ \\ ${ }^{1}$ Dairy Technology Department, Animal Production Research Institute, Egypt
}

(First received 15 April 2020 and in final form 5 June 2020)

(DOI: $10.31590 /$ ejosat.738337)

ATIF/REFERENCE: Elnemr, A. M., Ahmed, M. A., Arafat, H. H. O. \& Osman, S. (2020). Improving the Quality ff Camel Milk Soft Cheese Using Milky Component (BMR) and Sweet Potato Powder. European Journal of Science and Technology, (19), 566-577.

\begin{abstract}
The present study was designed to evaluate the effect of replacing 20 or $30 \%$ of camel milk with a milky component, had (BMR) secret code, in a trial to overcome the problem arising when soft white cheese was making. Supplementation with 1,2 and 3\% sweet potato powder SPP was, also, done to improve the quality and the nutritive value of the resultant cheese. Results indicated that fortifying camel milk with BMR and SPP improved the physic-chemical properties of cheese by reducing the pepsin coagulation time, whey syneresis and $\mathrm{pH}$ value compared with control cheese. Yield, titratable acidity and curd tension were increased with increasing the levels of additives used. These additives, also, increased the total solids, fat, protein, ash, salt contents as well as, values of cheese ripening indices and total volatile fatty acids in treated cheeses, after 30 days of storage period. There were clear differences in the microstructure among control cheese and the treated ones, in the shape, homogenization, compact or open body \& texture of the casein micelles network. Variations were, also, noticed in the size and numbers of voids or vacuoles and fat globules, owing to the variations in the chemical composition, manufacturing conditions and to the supplemented agents used. These observations were reflected on the body and texture of control cheese which became weak, loose and open. Moreover, addition of BMR and SPP improved greatly the texture profile of cheese and their technological aspects.
\end{abstract}

\section{Introduction}

Milk is considered the most important product obtained from camel (Dromedary), being a complete food, helps to provide a nutritious and balanced diet to nomadic desert people under harsh conditions. It is a major source of protein, fat, lactose, vitamins and minerals. Protein of camel milk contains all essential amino acids while, fat contains unsaturated aliphatic fatty acids. Camel milk contains, also, more whey protein, lower as1-casein content and a very low ratio of kappa-Casein to beta-Casein than in cow milk (Kappeler et al., 1998). All these parameters influence the technological aspects of the acidic or enzymatic coagulation process of that milk, so the resultant curd is almost being weak, fragile and had open body \& texture. Recently, camel milk was, also, reported to have other potential therapeutic properties, such as anti-carcinogenic and anti-diabetic (Agrawal et al., 2007), anti-hypertensive (Quan et al., 2008) and has been recommended to be consumed by children who are allergic to bovine milk (El-Agamy et al., 2007). Camel milk is consumed, usually, in a raw form by the people living in remote areas where camels are reared. In some occasions, to extend its shelf-life, this milk is consumed in a fermented form, as in Central Asia, such as fermented milk products (Konuspayeva et al., 2003). Other camel dairy products such as yoghurt (Hashim et al., 2009), butter (Tesfamariam et al., 2013) or cheese (Jones Abeiderrhamane, 2013)are not common on the national markets. In the other cattle milks, coagulation is faster than camel milk, since the casein micelles of the former milks are very smaller in size and coagulated within a short period of time (Bintsis and Papademas, 2017). However, the processing of camel milk into cheese is technically more difficult than the milk of the other domestic dairy animals under the same conditions. This is mainly due to the lower contents of total solids content, $\alpha$ s1- casein and k-casein as well as the large casein micelles which may relate to the poor rennet ability of camel milk (Hailu et al., 2018 and konuspayeva, et al., 2017). But success can be achieved when $\mathrm{pH}$ of milk is lowered, calcium chloride is added and raising the renneting temperature

* Corresponding Author: Dairy Technology Department, Animal Production Research Institute, Egypt, ORCID: 0000-0003-0441-7586, amal_elnimr@yahoo.com, hatemhelmy1412@gmail.com 


\section{Avrupa Bilim ve Teknoloji Dergisi}

prior to coagulation process (Shahein, et al., 2014). (Mehaia, 1993) added that camel milk failed to form gel- like structure after $18 \mathrm{~h}$ of incubation with lactic acid culture, owing to the presence of antibacterial substances such as lysozymes, lactoferrin and immunoglobulin compounds (El -Agamy, 2009).Therefore, several studies have advised to use milk ultrafiltrated (UF) retentate for standardization the camel milk prior to cheese-making, this supplementation had several potential benefits e.g. increasing the total solids and subsequently increasing the yield, facilitating the coagulation process, improving the organoleptic \& the rheological properties as well as the nutritional value of the resultant cheese (Green, et al., 1981).The use of ultrafiltration technique for standardized the total solids of camel milk to produce soft white cheese has been reported by (Mehaia, 2006). Milk concentrated by UF has been shown to produce good quality cheese (smooth and creamy body), improves both the curd firmness and the nutritional value owing to the higher protein, fat, calcium and phosphorus contents in the final product. Whereas, fresh soft white cheese produced from camel milk without using retentate was reported to have weak body \& texture, due to the lower contents of total solids as well as $\alpha$ s1-casein and K-casein in camel milk (Green, et al., 1981).

Sweet potato is a good functional food for people involved in heavy muscular work, since it contains high levels of carbohydrates which make up $90 \%$ of dry matter (the major carbohydrate components is starch, being 60-70\% amylopectin and 20-30\% amylose), protein, beta-carotene, vitamins (A, B6, C and E) and minerals (Potassium, phosphorus, manganese and zinc) which have several health benefits (Onabanjo and Ighere, 2014). Sweet potato powder is an important ingredient from the technological and nutrition aspects because it is a good source of starch which is used as a functional component either in industrial applications or in food processing. Starch has the ability to work as a thickener agent (Sameen, et al.,2017), improving the body and texture as well as reducing cracks in the surface of the curd (Januario, et al., 2017). Sweet potato contains, also, powerful antioxidants, which remove the free radicals from the body (these free radicals are harm chemicals that damage cells), fiber and pectin which are useful in preventing digestive disorders Such as hemorrhoids, constipation and fighting colon cancer (Surayia-Zakit, et al., 2008). Little studies were found about the use of UF buffalo milk retentatein the manufacture of white soft cheese from dromedary camel's milk. Therefore, the present work is focused on the production of camel milk cheese from whole camel milk after partially replacement a part of that milk with BMR as well as supplementation with sweet potato powder (a nutritive and healthy functional ingredient) in a trial to overcome the problems arising during manufacturing of this type of cheese. Physic-chemical, rheological, textural, microstructure and sensory properties of the resultant cheese, when fresh and during storage at $5 \pm 1{ }^{\circ} \mathrm{C}$, were done.

\section{Materials and Methods}

\section{Materials}

Cooled fresh whole camel milk was obtained from the herd of Camel Research Center, Marsa- Matrough Government, Egypt. The milky component (BMR) was obtained from the Dairy Processing Unit, Animal Production Research Institute. Yoghurt starter (Streptococcus thermophilus and lactobacillus delbrueckii sp. bulgaricus) and pepsin bovine powder (5N) were obtained from Chr. Hansen Laboratories, Copenhagen, Denmark. Sweet potato roots and table salt were bought from the local market. Calcium chloride is a product of Merck (Denmark).

\section{Rheological Tests:}

Pepsin Coagulation Time of Milk (PCT): was determined using $0.1 \mathrm{ml}$ of $5 \%(\mathrm{~V} / \mathrm{V})$ bovine Pepsin enzyme in distilled water per $10 \mathrm{ml}$ of milk in a thermostatically controlled water-bath, at $37^{\circ} \mathrm{c}$ and the time taken to the first signs of coagulation was measured for all samples as described in the Berridge method (1952).

Curd tension \& syneresis: were determined using the method of (Shalabi, 1987) for curd tension, and (Marshall, 1982) for curd syneresis (whey separation)..

\section{Methods}

\section{Preparation of sweet potato powder}

Cheese was manufactured according to the method applied by (Fahmi and Sharara, 1950) and modified by (El-Safty et al., 1983).Using Pepsin bovina instead of rennet calves ,Seven treatments were done using camel milk, (BMR) and sweet potato powder (SPP) as follows:

$$
\begin{aligned}
& \text { Camel milk without any additives........... Control (C) } \\
& 80 \% \text { camel milk }+20 \% \text { BMR, }+1.0 \% \text { SPP. } \\
& 80 \% \text { camel milk }+20 \% \mathrm{BMR},+2.0 \% \mathrm{SPP} \\
& 80 \% \text { camel milk }+20 \% \mathrm{BMR},+3.0 \% \mathrm{SPP} \text {. } \\
& 70 \% \text { camel milk }+30 \% \mathrm{BMR},+1.0 \% \mathrm{SPP} \\
& 70 \% \text { camel milk }+30 \% \mathrm{BMR},+2.0 \% \mathrm{SPP} \text {. } \\
& 70 \% \text { camel milk }+30 \% \text { BMR },+3.0 \% \text { SPP }
\end{aligned}
$$

Milk of all treatments were heat-treated at $65^{\circ} \mathrm{c}$ for $30 \mathrm{~min}$., cooled to $42^{\circ} \mathrm{c}, 0.04 \%$ calcium chloride, $3 \%$ sodium chloride, and $1 \%$ yoghurt culture were added. All treatments were incubated at $42^{\circ} \mathrm{c}$ for $30 \mathrm{~min}$. to pre-ripening the milk and Pepsin enzyme powder at a rate of $4 \mathrm{gm} . / 100 \mathrm{Kg}$ was added to all treatment. After coagulation, draining was done in 24 hours and the resultant cheeses were 
packed in plastic containers, pickled in $5 \%$ brine solution for 4 weeks, kept in a refrigerator at $(5 \mathrm{C} \pm 1)$ and analyzed when fresh and after 10, 20 and 30 days of storage for physic-chemical, textural profile, rheological, microstructure and sensory properties.

\section{Cheese yield:}

The quantities of cheese of all treatments were weighted on an electric scale balance (Akinloye and Adewumi, 2014). Cheese yields were calculated as a weight of cheese divided by weight of milk and expressed as a percentage.

\section{Methods of analysis}

\section{Physic-chemical Methods}

Camel milk, BMR, sweet potato powder and cheese samples were analyzed for total solids, titratable acidity ,fat, ash and salt, according to the methods described by (AOAC, 2007).Total nitrogen, soluble nitrogen and Non protein nitrogen were determined by semi micro kjeldahyl method (IDF, 1993). pH values were measured in triplicates using an electric $\mathrm{pH}$ meter with combined glass electrodes (Jenway 3305, England).Total volatile fatty acids (Kosikowski, 1978). Carbohydrate contents (Ceirwyn, 1995), using the following formula:

$$
\text { Total carbohydrates } \%=100-(\% \text { fat }+\% \text { protein }+\% \text { ash }+\% \text { moisture }) \text {. }
$$

\section{Cheese textural profiles}

Carried out using universal testing machine, Provides with software $35 \mathrm{~mm}$ diameter compression disc. Two cycles were applied, at a constant crosshead velocity of $1 \mathrm{~mm} / \mathrm{s}$, to $40 \%$ of sample depth and then returned. From the resulting force- time curve, the value for texture attributes i.e. Firmness, Gumminess, Chewiness and Adhesiveness. Cohesiveness and springiness were calculated from the Texture profile analysis (TPA) graphic (Bourne, 2003).

\section{Microstructure examination}

The electron microscopic analysis was performed in the Egyptian Mineral Resources Authority Central Laboratories Sector. The Scanning Electron Microscope (SEM) for fresh camel's milk cheese samples was carried out using SEM (FEL Company, Nether lands). Model Quanta 250 FEG (Field Emission Gun) attached with EDX unit (Emerge Dispersive Ray Analysis), with accelerating Voltage $10 \mathrm{KV}$. During SEM Analysis, samples were freezer fractured in liquid nitrogen to approximately 1-mm pieces and the pieces were then mounted on aluminum stubs with silver paint, dried to critical point and coated with gold for $300 \mathrm{~cm}$ sputter coater (SCD 005 Sputter Coater) and scanned under low vacuum conditions with pressure chambers $60 \mathrm{~Pa}$. (Karami et al., (2009).

\section{Sensory evaluation:}

Camel milk cheeses were judged by 10 panelists from the staff members of Dairy Science and Technology Department, Animal Production Research Institute using Scale points of, 15 for appearance and color, 35 for body and texture and 50 for flavor (Nelson and Tourut, 1965). All cheese samples were evaluated when fresh and after 10, 20 and 30 days of storage.

\section{Results and Discussion}

\section{Chemical composition of camel milk, BMR and potato}

Table (1a) indicates the chemical composition of whole camel milk (CM),(BMR) and sweet potato powder (SPP). Data revealed that CM had low contents of total solids (TS) and protein, while BMR had high levels of TS, protein and fat contents. SPP contained high amount of carbohydrates $(82.26 \%$ ) and low levels of fat $(0.69 \%)$. (Ramet, 2001) reported that the most important factor affecting the composition of camel milk is water content. Chemical composition of camel milk was found approximately near from that mentioned by Zahida (2017).

Table 1a. Chemical composition of fresh camel milk, BMR and sweet potato powder

\begin{tabular}{|l|c|c|c|}
\hline Component \% & Camel milk & BMR & Sweet potato powder \\
\hline Total Solids & 11.58 & 35.67 & 89.64 \\
\hline Protein & 2.92 & 12.44 & 3.48 \\
\hline Fat & 3.30 & 16.76 & 0.69 \\
\hline Ash & 0.89 & 1.98 & 3.21 \\
\hline Total Carbohydrate & 4.47 & 4.50 & 82.26 \\
\hline pH & 6.62 & - & - \\
\hline Acidity \% & 0.17 & - & - \\
\hline
\end{tabular}

Table (1b) shows the distribution of protein fractions in camel milk compared with cow, and buffalo milk. Camel milk had the lowest values of $\alpha \mathrm{S} 1$-casein (22\%), K-casein (3.5\%) compared to the other animals .Contrarily, B-casein (65\%) was found the highest fraction in camel milk than that in the other milks ( Zahida, 2015).These findings were correlated greatly with the quality and properties of the resultant camel milk cheese. 
Avrupa Bilim ve Teknoloji Dergisi

Table 1b. Casein fractions of cow, buffalo, and camel milk

\begin{tabular}{|c|c|c|c|c|}
\hline Animals & $\boldsymbol{\alpha}$ S1-casein \% & $\boldsymbol{\alpha S 2}$-casein \% & B- casein & K- casein \\
\hline cow & 38 & 10 & 39 & 13 \\
\hline buffalo & 38 & 16 & 36 & 13 \\
\hline camel & 22 & 9.5 & 65 & 3.5 \\
\hline
\end{tabular}

Source: (EL-Agamy et.al 2009; Park 2009; Brezoveckia et al. 2015)

\section{Physical properties of soft camel cheese}

It was clear that, replacing part of camel milk with (BMR) and sweet potato powder(SPP) resulted in increasing the titratable acidity (TA), curd tension (CT) and yield while, the $\mathrm{pH}$ value, pepsin coagulation time (PCT) and syneresis were decreased, compared to control cheese. This was more noticed with increasing the level of the former additives used (Table, 2). Yield, CT and TA for fresh control cheese were $13.22 \%, 7.0 \mathrm{~g}$ and $0.64 \%$, respectively, whereas the corresponding values for fresh cheeses contained $20 \%$ BMR and SPP (T1,T2 and T3) were ranged between 27.4-29.6\%, 13.1-16.2 g and 0.79-0.98\%, and those contained 30\% BMR \& SPP ( T4 ,T5 and T6 ) were 32.2 - 34.6\% , 17.6-19.6 g and 0.88-0.95\% , in order. Concerning the syneresis and PCT, it were highest in control cheese ( $39.40 \mathrm{ml} / 50 \mathrm{~g}$ and $240 \mathrm{~min}$.) Than in the other treatments, owing to the low total solids content and to the weak body $\&$ texture of the resultant cheese. Are verse relationship was found between syneresis \& PCT and the rate of additives used. These observations were in agreement with that found by Shahein, et al. (2014) who said that camel milk has more large casein micelles than that does in cow milk, which may relate to poor rennet ability of camel milk. Table (2) shows, also, that addition of BMR and SPP reduced greatly the rate of syneresis and PCT in the treated cheeses, because it contains high levels of TS, fat, protein and minerals especially calcium ions which improved and strengthen the body \& texture of the resultant cheeses. Furthermore, SPP act as a thickening agent (because of its high level of starch, $82 \%$ ). Farah \& Bachmann (1987) added, moreover, that the coagulation time of camel milk was reduced with decreasing $\mathrm{pH}$, with increasing temperature and added calcium chloride, but the differences in the coagulation time between camel and cow milk still remain ( two to three times longer than that in cow milk). It is known that factors affecting the yield of cheese were TS, TA, and the rate of recovery (Ramet, 1994b), as well as smaller casein micelles which contain high proportion of k-casein ( MC Gann et al. ,1988).

TA of all treatments were increased gradually along the storage period and cheese contained the highest percent of the additives recorded the highest values, after 30 days of cold storage. Results, also, indicated that $\mathrm{pH}$ values of all treatments behaved reverse trend to TA during storage.

Table 2. Changes in Physical properties of soft camel milk cheese supplemented with BMR and sweet potato powder, during cold storage.

\begin{tabular}{|c|c|c|c|c|c|c|c|}
\hline Treatments & $\begin{array}{l}\text { Storage period } \\
\text { (days) }\end{array}$ & $\begin{array}{l}\text { PH } \\
\text { va;ues }\end{array}$ & $\begin{array}{l}\text { Titratable } \\
\text { Acidity } \\
\text { (TA) }\end{array}$ & $\begin{array}{l}\text { Rennet } \\
\text { Coagulation } \\
\text { Time (min) }\end{array}$ & $\begin{array}{l}\text { Curd } \\
\text { tension(g) }\end{array}$ & $\begin{array}{l}\text { Curd } \\
\text { Syneresis } \\
(\mathrm{ml} / 50 \mathrm{ml})\end{array}$ & Yield\% \\
\hline \multirow[t]{4}{*}{ C } & Fresh & 5.18 & 0.64 & 240 & 7.00 & 39.40 & 13.22 \\
\hline & 10 & 5.12 & 0.67 & -------י & ------ & $\begin{array}{l}------ \\
\end{array}$ & ------ \\
\hline & 20 & 5.10 & 0.69 & ----- & ------ & ------ & ------ \\
\hline & 30 & 4.99 & 0,72 & ------- & ------- & ------ & ------ \\
\hline \multirow[t]{4}{*}{$T_{1}$} & Fresh & 5.14 & 0.79 & 212 & 13.1 & 28.70 & 27.4 \\
\hline & 10 & 5.11 & 0.83 & ------ & ------ & ------ & ------ \\
\hline & 20 & 5.01 & 0.87 & ------ & ------ & ------- & ------- \\
\hline & 30 & 4.81 & 0.94 & ------ & ------ & ------ & ------ \\
\hline \multirow[t]{4}{*}{$\mathrm{T}_{2}$} & Fresh & 5.09 & 0.82 & 206 & 14.8 & 26.10 & 28.5 \\
\hline & 10 & 5.03 & 0.88 & ------- & ------- & ------- & ------- \\
\hline & 20 & 4.87 & 0,92 & ------ & ------ & ------ & ------ \\
\hline & 30 & 4.73 & 0.98 & ------ & ------ & ------ & ------ \\
\hline \multirow[t]{4}{*}{$T_{3}$} & Fresh & 5.05 & 0,86 & 195 & 16.2 & 25.20 & 29.2 \\
\hline & 10 & 4.87 & 0.90 & ------- & ------- & ------- & ------- \\
\hline & 20 & 4.83 & 0.96 & ------ & ------ & ------ & ------ \\
\hline & 30 & 4.74 & 1.00 & ----- & ------ & ------ & ------ \\
\hline \multirow[t]{4}{*}{$\mathrm{T}_{4}$} & Fresh & 5.00 & 0,88 & 182 & 16.7 & 25.3 & 32.3 \\
\hline & 10 & 4.83 & 0.91 & ------ & ------ & $\begin{array}{l}------ \\
\end{array}$ & ------ \\
\hline & 20 & 4.87 & 0.93 & ------ & ------ & ------ & ------ \\
\hline & 30 & 4.74 & 0,97 & ------- & ------- & ------ & ------- \\
\hline \multirow[t]{4}{*}{$\mathrm{T}_{5}$} & Fresh & 4.92 & 0.92 & 174 & 18.1 & 22.20 & 33.7 \\
\hline & 10 & 4.87 & 0.94 & ------ & ------ & ------ & ------ \\
\hline & 20 & 4.78 & 0.97 & ------ & ------ & ------ & ----- \\
\hline & 30 & 4.68 & 1.02 & ------ & ------ & ------ & ------ \\
\hline \multirow[t]{4}{*}{$\mathrm{T}_{6}$} & Fresh & 4.86 & 0,95 & 160 & 19.6 & 20.12 & 34.6 \\
\hline & 10 & 4.73 & 0.98 & ----- & ----- & ------ & ----- \\
\hline & 20 & 4.67 & 1.03 & ------ & ------ & ------ & ------ \\
\hline & 30 & 4.61 & 1.06 & ------ & ------ & ------ & ------ \\
\hline
\end{tabular}


C: Control (C) cheese made from $100 \%$ camel milk.

$\mathrm{T}_{1}$ : Cheese made from $80 \%$ camel milk $+20 \% \mathrm{BMR}+1.0 \%$ sweet potato powder.

$\mathrm{T}_{2}$ : Cheese made from $80 \%$ camel milk $+20 \% \mathrm{BMR}+2.0 \%$ sweet potato powder.

$\mathrm{T}_{3}$ : Cheese made from $80 \%$ camel milk $+20 \% \mathrm{BMR}+3.0 \%$ sweet potato powder.

$\mathrm{T}_{4}$ : Cheese made from $70 \%$ camel milk $+30 \% \mathrm{BMR}+1.0 \%$ sweet potato powder.

$\mathrm{T}_{5}$ : Cheese made from $70 \%$ camel milk $+30 \% \mathrm{BMR}+2.0 \%$ sweet potato powder.

$\mathrm{T}_{6}$ : Cheese made from $70 \%$ camel milk $+30 \% \mathrm{BMR}+3.0 \%$ sweet potato powder.

\section{Chemical composition of fresh soft white camel cheese:}

It was noticed that control cheese had the lowest values of TS, protein, fat, ash and salt than the other treatments, along the storage period (Table, 3). Mehaia (1993) stated that the recovery of protein, fat and TS in camel milk cheese were 60,74 and $41 \%$, respectively. Farah (1996) added that about half of the fat in camel milk cheese is lost in the whey during draining. A direct relationship was found between the chemical composition of cheese and the rate of additives used (BMR \& SPP). This was apparent in cheeses contained the highest levels of these additives. The highest values of TS , fat and protein were noticed in fresh cheese (T6), contained 30\% BMR \& $3 \&$ SPP, being 52.78, 22.88 and $18.62 \%$, in order, while the corresponding values of control cheese were $34.39,13.20$, and $12.67 \%$, respectively. Table (3) shows, also, that value of ash and salt were found approximately near or similar in cheese of all treatments, during the storage period. Whereas values of protein in all cheeses were decreased through the storage period, owing to the proteolysis occurred by the microorganisms. Abdel- Salam et al. (1994) mentioned that the significant reduction in the protein content at 21 day of storage might probably due to the hydrolysis of proteins to water soluble nitrogenous compounds and to the diffusion of these products into the brine. On the other hand, Data in Table (3) cleared that TS, Fat, ash and salt contents were increased during storage as a result of increasing the TA and decreasing the moisture content (Mohamed et al., 2019). The fat contents of control camel milk cheese were low than the corresponding values of treated cheeses because of the fat globules of camel milk is very small and most of it retain in the whey liquid (Mohamed \& Larsson-Raznikiridis, 1990). Moreover, Ramet (2001) attributed that to the fragility of the casein micelles network of control cheese.

Table 3. Changes in the chemical composition of camel milk soft cheese as affected by BMR and sweet potato powder, during storage

\begin{tabular}{|c|c|c|c|c|}
\hline \multirow[t]{2}{*}{ Treatments * } & \multicolumn{4}{|c|}{ Storage period (days) } \\
\hline & Fresh & 10 & 20 & 30 \\
\hline \multicolumn{5}{|c|}{ 'Total Solid\% } \\
\hline Control(C) & 35.39 & 35.71 & 35.90 & 36.68 \\
\hline $\mathrm{T}_{1}$ & 46.75 & 46.85 & 46.92 & 47.50 \\
\hline $\mathrm{T}_{2}$ & 47.73 & 47.85 & 48.21 & 48.62 \\
\hline$T_{3}$ & 48.31 & 48.60 & 48.92 & 49.31 \\
\hline $\mathrm{T}_{4}$ & 51.66 & 51.33 & 51.97 & 52.65 \\
\hline$T_{5}$ & 52.03 & 52.68 & 52.91 & 53.21 \\
\hline$T_{6}$ & 52.78 & 52.92 & 53.52 & 53.88 \\
\hline \multicolumn{5}{|c|}{ 'Total Protein\% } \\
\hline Control(C) & 14.44 & 13.92 & 13.77 & 12.67 \\
\hline $\mathrm{T}_{1}$ & 18.23 & 17.83 & 17.65 & 17.49 \\
\hline $\mathrm{T}_{2}$ & 18.81 & 17.93 & 17.74 & 17.55 \\
\hline$T_{3}$ & 18.89 & 18.31 & 17.96 & 17.85 \\
\hline $\mathrm{T}_{4}$ & 19.22 & 18.87 & 18.51 & 18.39 \\
\hline $\mathrm{T}_{5}$ & 19.40 & 18.92 & 18.71 & 18.51 \\
\hline$T_{6}$ & 19.76 & 19.71 & 19.57 & 18.62 \\
\hline \multicolumn{5}{|c|}{ 'Total Fat\% } \\
\hline Control(C) & 13.20 & 13.41 & 13.62 & 14.25 \\
\hline $\mathrm{T}_{1}$ & 19.46 & 19.59 & 19.92 & 20.13 \\
\hline$T_{2}$ & 20.32 & 20.55 & 20.81 & 21.40 \\
\hline$T_{3}$ & 20.51 & 20.82 & 20.92 & 21.62 \\
\hline $\mathrm{T}_{4}$ & 22.21 & 22.46 & 22.71 & 22.91 \\
\hline $\mathrm{T}_{5}$ & 22.61 & 22.82 & 22.96 & 23.25 \\
\hline$T_{6}$ & 22.88 & 22.96 & 23.22 & 23.75 \\
\hline \multicolumn{5}{|c|}{ Ash\% } \\
\hline Control(C) & 2.91 & 3.03 & 3.11 & 3.17 \\
\hline $\mathrm{T}_{1}$ & 3.16 & 3.22 & 3.28 & 3.35 \\
\hline $\mathrm{T}_{2}$ & 3.20 & 3.24 & 3.33 & 3.38 \\
\hline $\mathrm{T}_{3}$ & 3.26 & 3.29 & 3.36 & 3.42 \\
\hline $\mathrm{T}_{4}$ & 3.35 & 3.34 & 3.41 & 3.45 \\
\hline$T_{5}$ & 3.42 & 3.45 & 3.56 & 3.60 \\
\hline$T_{6}$ & 3.49 & 3.55 & 3.59 & 3,67 \\
\hline
\end{tabular}


Avrupa Bilim ve Teknoloji Dergisi

\begin{tabular}{|l|l|l|l|l|}
\hline \multicolumn{5}{|c|}{ Salt\% } \\
\hline Control(C) & 2.61 & 2.64 & 2.69 & 2.71 \\
\hline$T_{1}$ & 2.64 & 2.67 & 2.74 & 2.77 \\
\hline$T_{2}$ & 2.66 & 2.70 & 2.75 & 2.79 \\
\hline$T_{3}$ & 2.69 & 2.74 & 2.77 & 2.82 \\
\hline$T_{4}$ & 2.71 & 2.76 & 2.79 & 2.83 \\
\hline$T_{5}$ & 2.74 & 2.77 & 2.80 & 2.86 \\
\hline$T_{6}$ & 2.79 & 2.81 & 2.84 & 2.88 \\
\hline
\end{tabular}

*See Foot note Table 2.

\section{Cheese ripening indices:}

Data in (Table, 4) illustrated the development in ripening indices in control and treated cheeses contained BMR and fortified with SPP, during ripening. It is clear that, SN/TN, NPN, NPN/TN\% values in control cheese were obviously lower than that in the corresponding values of the other treatments (T1-T6). The main reasons for that was the reduction of moisture, protein and TS in control cheese. Cheeses contained the highest level of BMR (30\%) recorded the highest values of SN/TN and NPN/TN being 27.75-28.9 \% for SN/TN and 3.22-3.35\% for NPN/TN, after 30 days of storage, respectively. It could, also, be observed that these values of all treatments including the control sample were increased gradually, as the storage period progressed (30 days) or as the percentage of BMR and SPP increased.

Concerning the total volatile fatty acids (TVFA), it was noticed that it behaved the former trend of the ripening indices during storage, and the highest value was found in T6 (30\% BMR \& 3\% SPP) being 21.81 compared to control one which was 15.2.

Table 4. Changes in ripening indices and total volatile fatty acids** (TVFA) of soft white camel milk cheese as affected by BMR and SPP, when fresh and after 30 days of cold storage .

\begin{tabular}{|c|c|c|c|c|c|c|c|c|c|c|c|c|c|c|}
\hline \multirow{3}{*}{$\begin{array}{l}\text { Property } \\
\begin{array}{l}\text { Storage } \\
\text { period } \\
\text { (days) }\end{array}\end{array}$} & \multicolumn{14}{|c|}{ Treatments* } \\
\hline & \multicolumn{2}{|c|}{$\mathrm{C}$} & \multicolumn{2}{|c|}{$\mathbf{T}_{1}$} & \multicolumn{2}{|c|}{$\mathbf{T}_{2}$} & \multicolumn{2}{|c|}{$\bar{T}_{3}$} & \multicolumn{2}{|c|}{$\overline{T_{4}}$} & \multicolumn{2}{|c|}{$T_{5}$} & \multicolumn{2}{|c|}{$T_{6}$} \\
\hline & Fresh & $\begin{array}{l}\text { 30 } \\
\text { days }\end{array}$ & Fresh & $\begin{array}{l}30 \\
\text { days }\end{array}$ & Fresh & $\begin{array}{l}30 \\
\text { days }\end{array}$ & Fresh & $\begin{array}{l}30 \\
\text { days }\end{array}$ & Fresh & $\begin{array}{l}30 \\
\text { days }\end{array}$ & Fresh & $\begin{array}{l}\text { 30 } \\
\text { days }\end{array}$ & Fresh & $\begin{array}{l}30 \\
\text { days }\end{array}$ \\
\hline SN\% & 0.211 & 0.572 & 0.331 & 0.686 & 0.343 & 0.695 & 0.349 & 0.721 & 0.440 & 0.794 & 0.545 & 0.811 & 0.556 & 830 \\
\hline SN/TN\% & 9.178 & 23.64 & 12.83 & 25.41 & 13.21 & 26.45 & \begin{tabular}{|l|}
14.10 \\
\end{tabular} & 26.24 & 16.15 & 27.75 & 19.96 & 28.76 & 20.31 & 28.91 \\
\hline NPN\% & 0.023 & 0.071 & 0.029 & 0.084 & 0.032 & 0.089 & 0.036 & 0.095 & 0.038 & 0.092 & 0.043 & 0.094 & 0.046 & 0.097 \\
\hline $\begin{array}{l}\text { NPN/TN } \\
\%\end{array}$ & 1.000 & 2.934 & 1.124 & 3.111 & 1.236 & 3.278 & \begin{tabular}{|l|}
1.387 \\
\end{tabular} & 3.481 & 1.394 & 3.216 & 1.575 & 3.279 & 1.680 & 3.520 \\
\hline TVFA & 6.8 & 15.2 & 8.04 & 19.75 & 8.16 & 19.83 & 8.19 & 20.41 & 9.48 & 20.79 & 9.85 & 21.31 & 10.41 & 21.81 \\
\hline
\end{tabular}

*See Foot note of Table 2 .

** $\mathrm{ml} / 0.1 \mathrm{~N} \mathrm{Naoh} / 100 \mathrm{~g}$ cheese.

\section{Textural profiles of camel milk cheese:}

Rheology of materials e.g., cheese, may be defined simply as the study of their deformation and flow when subjected to a stress or strain .The textural property is one of the important parameter used to evaluate the quality of cheese. Owing to the variations in manufacturing conditions and composition, different cheese varieties exhibit a wide range of rheological behavior, ranging from the viscous behavior of soft cheese to the elastic behavior of hard cheeses at low strain .Data in (Table, 5) clear that, the changes in the texture characteristics of all cheese treatments during ripening period. It was observed that these values of texture profiles were increased in treated cheeses in a higher rate, during 30 days of ripening, compared with control cheese. This may be due to the decreasing of moisture content and increasing of acidity, which resulted in firmer texture as a result of the alterations, occurred in the case in matrix (Fredrick and Dulley, 1984). Also, it was noticed that the minimum values of texture profiles were present in fresh cheeses and these values were gradually increased, in all treatments, reaching the maximum values, at the end of the storing period.

Addition of BMR and SPP improved greatly the texture profile of the resultant treated cheeses compared with control. Our results showed, moreover, that the higher values of hardness, cohesiveness, springiness, gumminess and chewiness, among the treated cheeses, were noticed in T6, while the lowest one was found in T1.This may be due to the variations in the chemical composition and the percentages of the additives used. (Akalin et al., 2012) observed that the addition of BMR to milk increased the total solids content, which resulted in an increase in the density, and reduced the pore sizes in the protein matrix of the yoghurt gel, and leading to a reduction in the syneresis by improving its water holding capacity .Furthermore, Van Hekken, et al. (2007) found that 
European Journal of Science and Technology

increasing the firmness of soft cheese during storage was probably due to the decrease in moisture content, because water molecules within the three dimensional protein matrix weaken the network structure, and consistency of protein matrix increases , resulting in firm products. Farah \& Bachmann (2007) added that the size distribution of casein micelles in camel milk is significantly broader than that of cow milk with a greater number of large micelles of 350 to $500 \mathrm{~nm}$. Smaller diameter micelles, which contain high proportion of k-casein, give firmer curd and more compact body than large micelles at the same total casein, by raising the amount of positively charged hydrophobic para-k-casein on the surface of micelles. The former information's supported our results concerning the supplementation of camel milk with BMR, which increased the amount of small casein micelles and k-casein in the treated cheeses and consequently improved its firmness. In addition, enrichment in calcium ions (by adding BMR) generates additional links, which strengthen the cohesion of the casein micelles network (FAO, 2011). Finally, it is worth to note that the differences noticed among the cheese of all treatments may be linked to cheese $\mathrm{pH}$, degree of proteolysis and the polar characteristics of fat and protein fractions. Increasing the water binding capacity of the curd, leads to decrease in adhesiveness of cheese Mohamed et al., (2019).

Table 5. Changes in rheological characteristics of different treatments of soft white cheese made from Camel milk as affected by supplementing with BMR and SPP, when fresh and after 30 days of cold storage

\begin{tabular}{|c|c|c|c|c|c|c|c|c|}
\hline \multirow[t]{2}{*}{ Parameter } & \multirow{2}{*}{$\begin{array}{c}\text { Storage } \\
\text { period } \\
\text { (days) }\end{array}$} & \multicolumn{7}{|c|}{ Treatments* } \\
\hline & & $\mathbf{C}$ & T1 & $\mathbf{T 2}$ & T3 & T4 & T5 & T6 \\
\hline \multirow{2}{*}{$\begin{array}{l}\text { Hardness } \\
\text { (kg) }\end{array}$} & 1 & 2.136 & 4.040 & 4.38 & 4.450 & 4.463 & 4.614 & 4.709 \\
\hline & 30 & 4.342 & 6.524 & 6.75 & 6.811 & 6.840 & 6.895 & 6.973 \\
\hline \multirow[t]{2}{*}{ Cohesiveness } & 1 & 0.207 & 0.312 & 0.413 & 0.565 & 0.578 & 0.646 & 0.711 \\
\hline & 30 & 0.334 & 0.730 & 0.873 & 0.987 & 0.993 & 1.072 & 1.145 \\
\hline \multirow{2}{*}{$\begin{array}{l}\text { Springiness } \\
(\mathbf{m m})\end{array}$} & 1 & 0.275 & 0.459 & 0.545 & 0.744 & 0.763 & 0.771 & 0.794 \\
\hline & 30 & 0.298 & 0.778 & 1.082 & 1.302 & 1.309 & 1.318 & 1.336 \\
\hline \multirow{2}{*}{$\begin{array}{c}\text { Gumminess } \\
(\mathrm{kg})\end{array}$} & 1 & 0.637 & 0.949 & 1.378 & 1.383 & 1.396 & 1.405 & 1.417 \\
\hline & 30 & 0.758 & 1.240 & 1.671 & 1.672 & 1.688 & 1.715 & 1.726 \\
\hline \multirow[t]{2}{*}{ Chewiness } & 1 & 0.216 & 0.436 & 0.761 & 1.029 & 1.078 & 1.159 & 1.277 \\
\hline & 30 & 0.326 & 0.886 & 1.211 & 1.479 & 1.552 & 1.606 & 1.721 \\
\hline
\end{tabular}

*See Foot note Table 2 .

\section{Cheese Microstructure:}

The cheese matrix was, generally, made up of protein network in which fat globules are embedded and voids (black area) occupied by the water phase in the cheese. As it is known, cheese consists primarily of fat, protein, minerals, lactic acid and water. Protein form the major structural network of the cheese (appeared in the micrograph as a grey area) and entrap the fat. Protein, mainly casein, contributes to hardness, and fat and water contribute to smoothness. Calcium and its interactions with proteins, also, influence body and texture (Lawrence, et al., 1984). Scanning electron micrographs of control and treated fresh cheeses in our study contained BMR and SPP are shown in (Fig. 1\&2). It was noticed that control cheese (picture, 1A) was characterized by granularly casein micelles network, not homogenous well, had low numbers of fat globules, and contained large whey voids or vacuoles. The number and size of voids were found much than that in the other treated cheeses. These observations resulted in weak, loose and open body and texture of that cheese, which noticed previously during the evaluation of the organoleptic properties.

The use of BMR (20 or $30 \%$ ) in the manufacture of camel milk cheese improved greatly the microstructure of the resultant cheeses, to be homogenous and had large stretched of continuous protein matrix interspersed with serum channels (Pictures. 27).The granular shape of casein micelles noticed in control cheese was approximately disappeared .Micrographs revealed, also, that the protein matrix networks were of compact body \& texture, had much accounts of fat globules, and as the percent of BMR increased the improvement of the resultant cheese was increased.

The utilize of SPP either in 20 or $30 \%$ BMR cheeses, resulting in voids full of complex like-gel with whey (W+P), owing to the higher levels of starch (44-78 \%) in the SPP, which had high water-binding ability (Pictures.2-7). As the level of SPP increased, the number and size of $\mathrm{W}+\mathrm{P}$ voids increased. Casein micelles of cheese containing the highest percent of SPP were linked strongly with the improvement of the organoleptic properties of cheese, especially hardness of firmness.

From the previous observations, it was noticed, generally, that there were clear differences in the microstructure among all treatments, and this may be due to the variations in its chemical composition, manufacturing conditions and to the supplemented agents used. 
Avrupa Bilim ve Teknoloji Dergisi

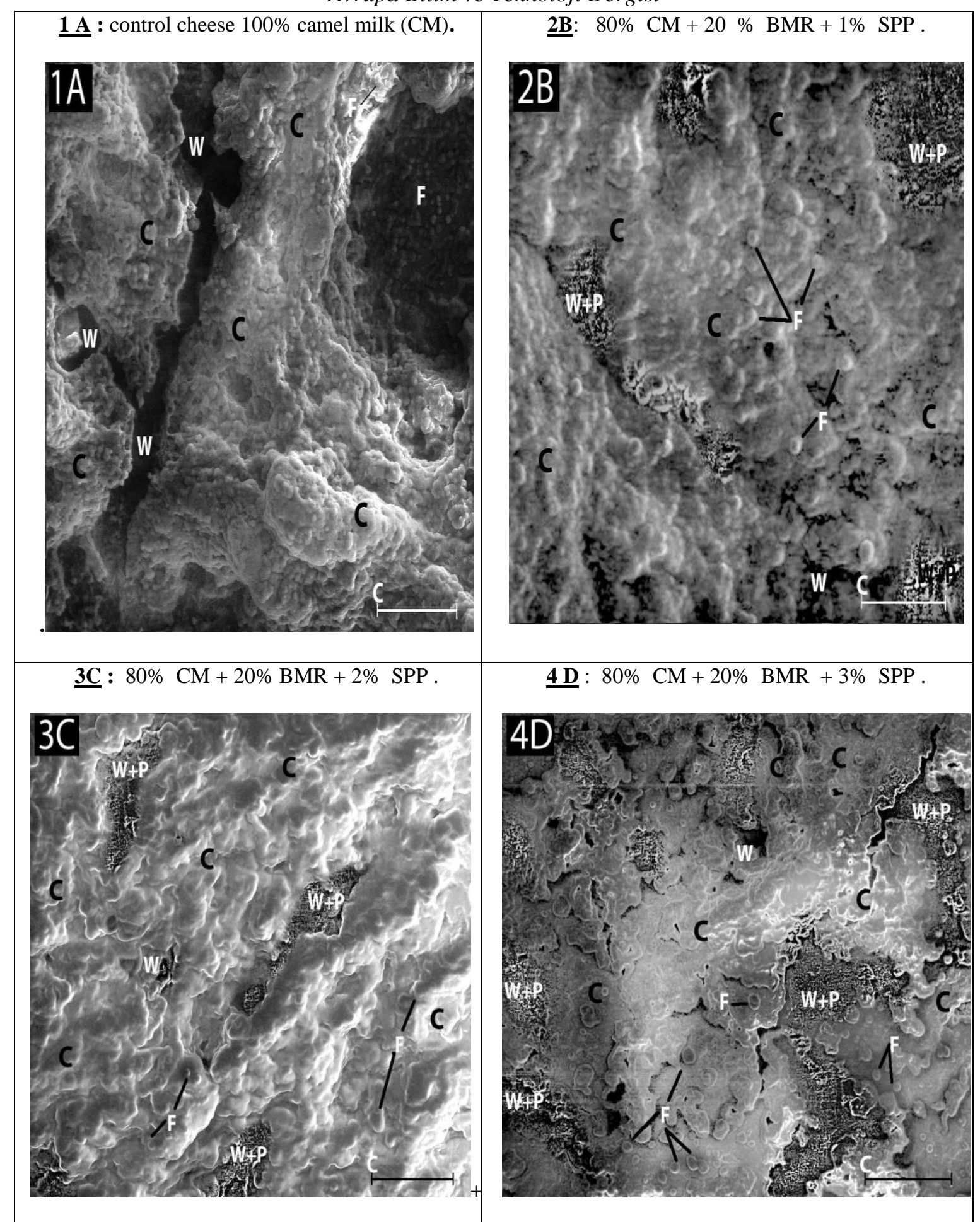

Fig. 1. Micrographs of fresh camel milk cheese made using BMR and sweet potato powder. C: casein, W: Whey, F: fat globule, C-J: curd junction, $\mathrm{W}+\mathrm{P}$ : whey+ sweet potato powder 




Fig. 2. Micrographs of fresh camel milk cheese made using BMR and sweet potato powder. C: casein, W: Whey, F: fat globule, C-J: curd junction, $\mathrm{W}+\mathrm{P}$ : whey+ sweet potato powder

\section{Sensory evaluation:}

Sensory evaluation revealed that color \&appearance, body \& texture and flavor of treated cheeses were affected, generally, by the different levels of supplementation and the storage period. Results, also, showed that the use of BMR, and SPP and calcium chloride increased greatly the sensory attributes of the resultant cheese, especially its flavor and body \& texture as compared with the control cheese. These results confirmed the report which pointed out that curd firmness, measured either by empirical or instrumental methods were multiplicative after adding milk protein concentrated to camel milk (Shamas, et al., 2003). 


\section{Avrupa Bilim ve Teknoloji Dergisi}

After 30 days of storage, improvement has been happened in the flavor and body \& texture of cheese of all treatments. Our results revealed, moreover, that a positive relationship was found between the sensory properties of the cheese and the rates of additives used. The highest degree of flavor, body \& texture and appearance were found in samples contained the highest levels of BMR and SPP (T4-T6), all over the storage period. Whereas, the lowest ones were found in control cheese, which characterized by less compact body \& texture and loose network.The main reasons for that were probably due to the low TS content of camel milk and to the differences in the fractions of camel milk protein than in cow milk. Camel milk had lower percent of $\alpha \mathrm{s} 1$-casein and k-casein and higher percent of $\beta$-casein (Table, 1b). Farah \& Bachmann (1987) noticed, also, the former observations and stated that the total casein content in camel milk varies between 1.9 -2.3\% and is lower than that of cow milk (2.8-3.2\%). A difference between camel and cow milk regarding the size dimensions of the casein micelles were noticed also. The previous results were agreed with that found by (El-Zubeir and Jabreel, 2008) who reported that the general sensory features of camel milk cheese are light soft coagulum with a higher moisture content.

\section{Conclusion}

This study demonstrated that the manufacture of fresh soft white cheese from camel milk fortified with (BMR) was most acceptable and improved the processing parameters such as (clotting time, curd firmness, syneresis, yield and shelf life). Cheese made from camel milk without the use of BMR had weak body \& texture and inferior flavor along the storage period. Supplementation of camel milk with sweet potato powder (SPP) resulting in an increase in the amylose content (which leads to increase the starch retro graduation) and consequently, producing firmer gel, because starch act as a thickening agent.

Addition of BMR and SPP together improved greatly the quality and the sensory properties, especially curd firmness and consistency, of the resultant cheese.

\section{References}

Abd El-Salam MH, Alichanidis E, Zerfiridis GK (1994). Cheese: chemistry, physics $\quad$ Microbiology: Domiati and Feta-type cheeses. (2ndedn), Springer-Verlag, USA. .

Agrawal, R.P., Budania, Sharma, R. Gupta and D.K. Kochar, (2007). Zero prevalence of diabetes in camel milk consuming Racia community of North-West Rajusthan. India. Diabetes Research and Chemical practice, Make references like this style, $76: 290$ 296.

Ahmed, N.A.A., and el-Zubeirm I.E.M. (2011). Effect of salt level on some physical and chemical properties and acceptability of camel milk cheese. Journal of Camelid Science 4: 40 -48.

Akalin, A.S.; Unal, G.; Dinkci, N. and Hayaloglu, A.A. (2012). Microstructure, textural and sensory characteristics of probiotic yoghurt fortified with sodium calcium caseinate or whey protein concentrate. J.Dairy Sci. 95 (7), 3617-3628.

Akinloye, A.M. and O.O. Adewumi.(2014) .Effects of local coagulants on the yield of cheese using cow and sheep milk. Int. J. Develop. Sustain. 3 (1): 150-161.

A.O.A.C (2007). Association of Official Analytical Chemical Chemists, Official Methods of Analysis, Vol. 118 ${ }^{\text {th }}$ ed. Washington, D.C.

Berridge, N.J. (1952). Some observations on the determination of the activity of rennet. Analyst, $77: 57$.

Bintsis, T. and P. Papademas.( 2017) .An overview of the cheese making process.In: P. papademas and T. Bintsis (eds). Global cheese making Technology. P. 120-156.

Bourne, M.C., (2003). Food texture and viscosity: Concept and measurement. Elsevier Press, New/London.

Brezovecki ,A M. Cagalj, Z.F. Dermit , N. Mikulec, D.B. Ljolic and N. Antunac (2015). Camel milk. Mljekarstvo 65 (2): $81-90$.

Ceirwyn S.J., (1995). Analytical chemistry of foods. Part 1 Pub. Bluckie Academic a professional P. 135.

Collado, L, S., and Corke, H. (1996).Use of wheat sweet potato composite flour in yellow alkaline and white salitednodles.Ceeal Chem. 73, 439 - 444.

EL-Agmy, E.L. (2007).The challenge of cow milk protein allergy. Department of Dairy Science, Faculty of Agriculture, Small Ruminant Research , Egypt. PP: 64-72.

El-Agamy, El, M. Nawar, S.M. Shamsia, S. Awad and G.F. W. Haenlem, (2009) .Are camel nutrition of cow milk allergic children Small R Rummant Research, 82: 1-6

El-Safty, M.S., A.A. Nofa 1 and A. Hekmat, (1983). The effect of acidic and basic amino acids mixtures on quality and ripening of Domiati cheese made from reconstituted milk. Egyptian J. Food Sci.11: 115 - 122.

El-Zubeir, IEM.Jabreel, MSO. (2008) .Fresh cheese from camel milk coagulated with camifloc. International Journal of Dairy Technology 61: 90-95.

El-Zubir, IEM.andSamah. O.J. (2008). Fresh cheese from camel's milk coagulated with Camilfloc. International Journal of Dairy Technology, 60: 90-95.

Fahmi, A.H. and H.A. Sharara, !950. Studies of Egyptian Domiati cheese. J. Dairy Res., 17: 312 - 328.

FAO (2011). Animal production and health. Paper 113-Ways of improving cheese made from camel milk .Rome 2011.

Farah, Z., (1993). Composition and characteristics of camel's milk. Journal of Dairy Research, 60: 603-620.

Farah, Z. (1996). Camel milk properties and products. St. Gallen, Switzerland: SKA. Swiss

Centre for Developments Cooperation in Technology and Management.

Farah, Z., and M.R. Bachmann (1987). Rennet coagulation properties of camel milk. Milchwissenschaft, 42, 689-692.

Fredrick, L.A. and Dulley, J.R.(1984).The effect of elevated storage temperature on the rheology of Cheddar cheese. N.Z.J. Dairy Technol., 68 (suppl. 1). 


\section{European Journal of Science and Technology}

Govindasamy Lucey, S.; Jaeggim J.J.; martinelli, C.; Johnson, M.E.; Lucey, J.A. 2011. Standardization $\quad$ of $\quad$ milk using cold ultrafiltration retentates for the manufacture of Swiss cheese: Effect $\mathrm{pH}$ altering coagulation conditions on yield and cheese quality. J. Dairy Sci. 94: 2719-2730.

Gnan, S.O. and Sheriha, A.M. (1986).Composition of Libyan camel's milk. Austr.J. of Dairy

Green, M.L.; Glover, F.A.; Scurlock, E.M.W.; Marshall, R.J.; Hatfield, D.S. (1981). Effect

Techn. 41 (1), 33-35

of use of milk concentrated cheddar cheese. J. Dairy Res. 48: 333-341. sensory properties and aroma compounds formed J. 81: 122- 130

Hashim, I.B., Khalil, A.H. and Habib, H.,(2009). Quality and acceptability of a set- type yoghurt made from camel milk. Journal of Dairy Science, 92: 857-862.

IDF (1993). International Dairy Federation.Nitrogen content of milk and milk products. Annual Sessions Tokyo, Japan.

Januario, J.G.B.; da silva, I.C.F.; de Oliveira, A.S.; Oliveira, J.F.; Dionisio, J.N.;Klososki, S.J.; Pimentel, T.C. (2017). Probiotic yoghurt flavored with organic beet with carrot, cassava sweet potato or corn juice: Physicochemical and texture evaluation, viability and acceptance, Int. Food Res. J., 24, $359-366$.

Jones-Abeid-errhamane N., (2013). Camel cheese: seemed like a good idea. publnancyJones Abeiderrhamane, Nouakchott Mauritania $387 \mathrm{p}$.

Kailasapathy, K. 2006. Survival of free and encapsulated probiotic bacteria and their effect yoghurt. LWT 39 (10): $1221-1227$.

Kappeler, S., Farah, Z. and Puhan, (1998). Sequence analysis of camelusdromedaries milk 222.

Karami, M., Ehsani, U.R.Mousavi, SM., Rezaei, K. and Safari, M. (2009).Changes in the rheological properties of lranian UF.Feta cheese during ripening. Food chem.., 112: 539.

Konuspayeva, G., Faye B., Serikbaeva A., 2003). Les produitlaitierstraditionnels a baeedf 1 lait dechamelle en Asie ventral. Atelier Int. sure le lait de chamelle en afrique FAO-CIRAD- KARKARA, Niamey, Niger. 5-8/ 11/03, 71-82.

Konuspayeva, G., B. Camier, N. Aleilawi, M. Al-Shumeimri, K.Al-Hammad, K. Algruin,F.Alsh ammari, E. Beaucher and B. Faye,(2017).Manufacture of dry-and brine-salted soft camel cheeses for the camel dairy industry. Int. J. Dairy

Technol. 70: 92-101.

Lawrence, R.C.; H.A. Hepa and Gilles (1984): "A controlled approach to cheese technology". J. Dairy Sci., 67: 1632.

Kosikowski, F.V. (1978). Cheese and Fermented Milk Foods. Published by the Author. Camel, Univ. Ithaca, New York, USA.

Marshall, R.G. (1982). An Improved method for measurement of the synersis of curd formed by rennet action on milk. J. Dairy Res.49: 329 - 336.

Mehaia, A.M. (1993). Fresh soft white cheese (domiati type) from camel's milk: composition, yield and sensory evaluation. Journal of Dairy Science, 76: 2845-2855.

Mehaia, M.A. (2006) . Manufacture of Fresh Soft White Cheese (Dommiati Type) from Dromedary camel milk using ultra filtration process. Journal of Food Technology 4: 206-212.

Mohammed S., Eshetu M., Tadesse Y. and Hailu Y., (2019). Rheological Properties and Shelf Life of Soft Cheese Made from Camel Milk Using Camel Chymosin. Journal of

Article.

Mohamed, M. A. ,M . Larsson-Raznikiewicz, and M. A. Mohamed (1990). Hard cheese making from camel milk. Milchwissenschaft, 45:716.

Nelsonn, J.A. and G. M. Trout,( 1965). Judging Dairy Produces, $4^{\text {th }}$ Ed Olsen publishing Co. Milwaukeewis, and PP. 53312.

Onabanjo, O.O. and Ighere, D.A., (2014). Nutritional, functional and sensory properties of Biscuit produced from wheat sweet potato compost. Journal of Food Technology Research, 1(3): 111 -121.

Quan, S., H. Tsuda and T.M. Iyomoto, (2008). Angiotesin converting enzyme inhibitory peptides in skim milk fermented with Lactobacillus Helveticas 130B4 from camel milk Inner Mongolia China- Journal of the Science of Food and Agriculture, 88: 26882692.

Park, Y.W.( 2009) . Bioactive Components in Milk and Dairy Products. Chapter 6 .John Wiley and Sons Publishers.

Ramet, J.P. (1994b ). Production de fromages à partir de lait de dromadaire en Mauritanie Mission report. Rome, FAO. 60 pp.

Ramet, J.P, (2001). The Technology of Making cheese from camel's milk (Camelus dromedary). Animal production and Health paper, No. 113, FAO, Rome, Italy.

Sameen, A.; Mailzoor, M.F.;Huma, N.; Sahar,A.;(2017). Quality evaluation of ice cream Prepared with Sagudana (MeteroxylonSagu) and Sweet Potato (Ipomoea batatas) starch as stabilizing agent. Pak.J. Food Sci., 27, 1-6.

Sandhu, K.S., Kaur, M. and Mukesh.(2010). Studies on noodle quality of potato and rice starches and their blends in relation to their physicochemical, pasting and gel textural properties. LWT-Food Science and Technology 43 (8): 1289 -1293.

Shahein M.R. , A. M. Hassanein and Abeer F. Zayan (2014) . Evaluation of Soft Cheese Manufactured from Camel and Buffalo Milk. World Journal of Dairy \& Food Sciences, 9 (2) : 213- 219.

Shalabi S.I. (1987).Milk clotting activity of commercial rennet substitutes. A comparative 9: $441-460$.

Shamas, A.A., A.A. Al-Neshawy; M.S. Al-Wesali and S.H. Hamad, (2003). Utilization of camel milk in the manufacture of feta cheese.Egypt. J. Appl. Sci, 18: 189 - 208.

SurayiaZakir, Mohammed, S., Allen, J., Butt, M,S., Mehr, U.N., Umair, A., Islam. U.D. and A Asif Javaid (2008). Impact of sweet Potato Cultivars on blood glucose level in diabetic and healthy participants. International J. Of Agriculture and Biology 2008, $\quad 10(3): 316-320$. 
Tesfamariam B., eyassu S., Kurtu M.Y.,(2013). Physicochemical properties of butter made (2), 51-54.

Van Hekken D.L., Tunick, M.H., Tomasula P.M., Corral, F.J.M., Gardea, A.A., (2007). Mexican Queso Chihuahua: Rheology of fresh cheese. International Journal of Dairy

Technology, 60(1): 5-12.

Zahida, Q, Huzhathuma, Sameen, A. and lqbal, T. (2015). Camel milk cheese: Optimization of processing condition. Journal of Camiled Science, 8: 18-25.

Zahida, Q. (2017). Optimization for processing parameters for camel milk cheese production. PH.D thesis in Food Technology, Pakistan.

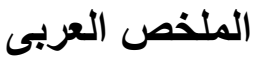 \\ تحسين جودة الجبن الأبيض الطرى الطازج المصنع من لبن الأبل باستخذام مكون لبني معين ومسحوق البطاطا لين البن}

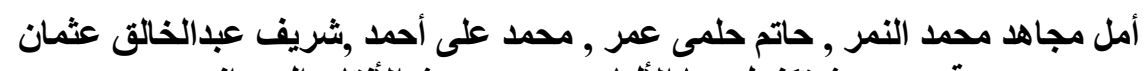

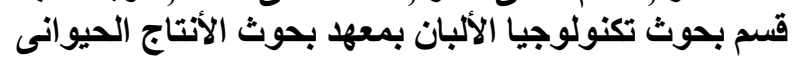

تهذف هذة الدر اسة الى تحسين جودة الجبن الطرى الطازج المصنع من لبن الابل وذلك باستبدال 20 , 30\% من لبن الابل

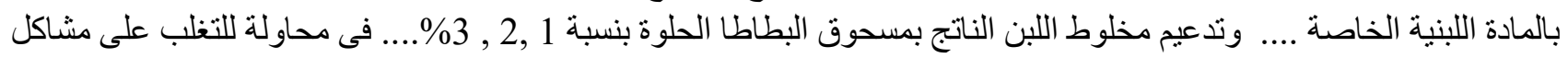

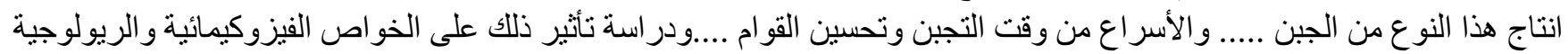

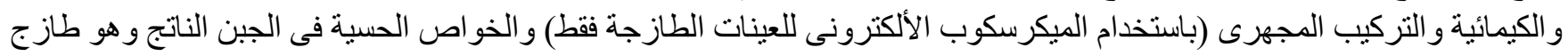
وخلال التخزين فى الثلاجة لمدة 30 يوم مقارنة بالكنترول المصنع من لبن الأبل فقط , ولقد أظهرت الطئ النتائج مايلى:-

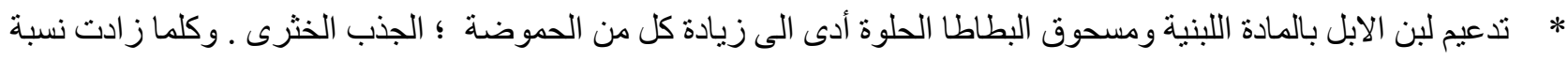

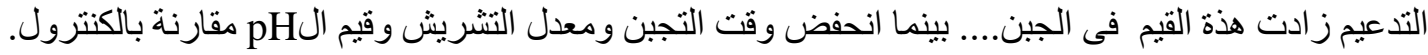

* أوضحت النتائج أن زيادة نسبة التدعيم بالمادة اللبنية ومسحوق البطاطا الحلوة أدى لزيادة كل من تصافى الجبن و الجو امد الكلية

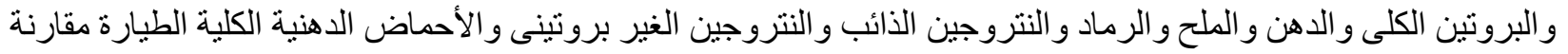

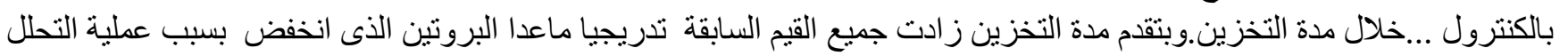
المائى بالانزيمات .

* اظهر الفصص بالميكرسكوب الألكترونى وجود اختلافات واضحة في التركيب الدقيق بين جبن المقارنة وباقى معاملات الجبن

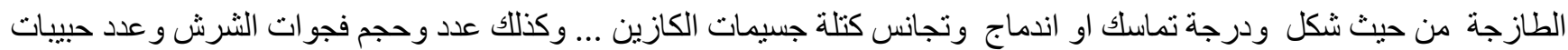

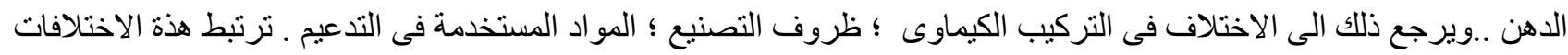

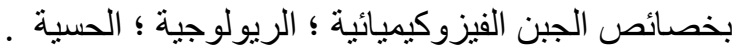

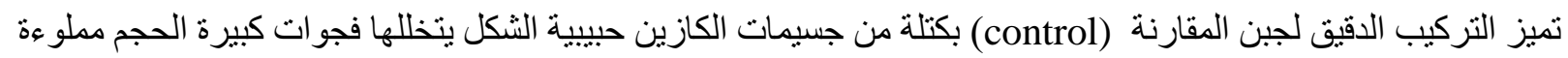
بالثرش ...ومنتشربهاعدد قليل من حبيبات الدهن ـ ادى اسخدام المادة اللبنية \& ومسحوق البطاطا الى تحسن كبير فى التركيب الدقيق

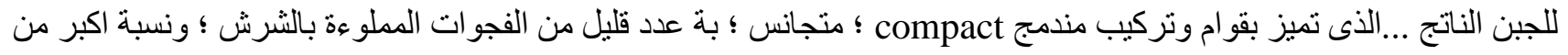
حبيبات الدهن . عموما يوجد علاقة طردية بين نسبة اضافة كل من المادة اللبنية الخاصة ومسحوق البطاطاوبين درجة التجانس فى التركيب الدقيق للجبن الناتج .

* أثـارت النتائج ايضا الى تحسن الخصائص الريولوجية للجبن المدعم بالمادة اللبنية الخاصة ومسحوق البطلطا الحلوة تحسنا كبيرا

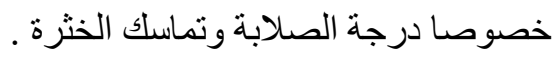



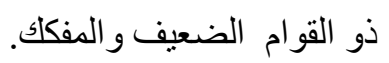
لذا يمكن التوصية باستخدام لبن الأبل (النوق) المدعم بالمادة اللبنية الخاصة ومسحوق البطاطا الحلوة فى انتاج جبن طرى ذو جودة حسية

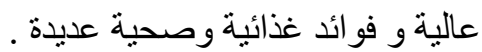

